\title{
Life in the Olympic Village: A view from Georgia Tech
}

\author{
By Donald G. Frank, Laura L. Greene, Lisa A. Macklin, Jillian Baker, Tanya Barber, \\ Laurie MacLeod Bennett, Katharine Calhoun, Tom Fisher, and Claire Oslund \\ Swanson
}

\section{The Olympic Games are over but the memories remain}

$\mathbf{A}$ S the Olympic Village for the 1996 Centennial Olympic Games, the campus of the Georgia Institute of Technology (Georgia Tech) was home for 13,500 athletes during the five weeks of the Olympic and Paralympic Games. The implications for the faculty and students of Georgia Tech were dramatic and extensive. Information services and the people who provide these services in the Library and Information Center were also affected by the Games. The Atlanta Committee for the Olympic Games (ACOG) assumed control of and responsibility for the campus in mid-June. In only five weeks, the campus was physically transformed from an acalemic community into the "sixth-largest city in Georgia," populated by athletes, coaches, trainers, and officials. ${ }^{.}$The first sign of change was a high, electrified fence which defined the borders of the Village. As the fence approached completion, the campus was no longer recognizable as an academic institution.

Transforming the campus into the Olympic Village required a Herculean effort for all concerned. New and renovated buildings, new landscaping, and other Olympic structures significantly changed the appearance and character of the campus. The Aquatic Center and the athletic dormitories were constructed in 1995 as permanent additions to the campus, to be used by students at the conclusion of the
Games. The Olympic Plaza, where flags of 197 countries fluttered in the breeze, included a new fountain and campanile, and served as the backdrop for the Today Show's daily broadcasts; it remains a campus focal point. Huge airconditioned pavilions and tents, a massive dining hall as large as a football field, and other buildings were erected all over campus. Other temporary structures included a cafe, clisco, swimming pool, amphitheater (for official welcoming ceremonies), and a "Surf Shack" of computers for electronic mail. The basic amenities of a city, including a bookstore, florist, general store, and hair salon, were available for the athletes.

\section{Schedules and security}

As the Games approached, library staff became increasingly apprehensive. With 15,000 people arriving at the Olympic Village and 2.5 million coming to Atlanta for the Games, occasional feelings of anxiety were natural. The campus and the library remained open for academic business. Officially, the library was open from 8:00 to 5:00, Monclay-Friday, so all staff members faced either a lengthier commute or using vacation leave. Flex time allowed many staff to start work as early as 6:00 a.m. to avoid heavy traffic. It was not possible to (rive onto campus. Therefore, staff parked at nearby lots or used MARTA, the public transportation system, and then took various shuttle buses to the campus. Despite clire predictions, automobile tratffic was not overwhelmingly heavy in the metropolitan area. However, stories of problems on MARTA were numerous and were accurately

Donald G. Frank, Lama L. Greene, Lisa A. Macklin, Jillian Baker, Tanja Barber; Lanmie MacLeod Bennett. Katbarine Calboun. Tom Fisher, and Claire Oslund Suanson are libravians at the Georgia Instilute of Technology; e-mail: don,frank@library.gatech.edu 
described by the national and international media.

Fach staff member navigated a series of security checkpoints to get onto campus. At the entrances, each person passed through metal detectors and had hand geometries scanned. This procedure allowed an exact match of each person's hand dimensions to his or her photo identification badge. Attachés, purses, and backpacks were carefully searched. One library staff member had a jar of peanut butter confiscated as it was deemed by a security guard to be potentially dangerous. Security increased as several bomb scares were reported and became especially intense after the bombing at Centennial Olympic Park

\section{Services and the games}

The campus became "secure" on June 15. From then until August 12, access to the Olympic Village was limited to individuals who had been checked and accredited by ACOG. As a result of the library's location in the Olympic Village, the only walk-in customers were Georgia Tech's ACOG-approved faculty, staff, and students.

Faculty and students unable to gain access to the library were served through electronic means and by phone. Staff members noted that some professors, who usually relied on their graduate students for library research, were using the library themselves. This provided an excellent opportunity to update them on recent changes in the library's online systems and homepages.

Many non-Tech customers were unaware of the library's secured status. Callers' reactions to the "state of siege" ranged from disappointed or frustrated to curious or sympathetic. As public awareness of Olympic security spread, the intensity of these calls lessened. Reference staff noticed a metamorphosis of their department into a referral center as they directed callers to other libraries or information sources. Many calls came from frustrated people in cars who were trying to get on campus; they were helped to escape the traffic maze and return to their offices or homes.

Several access-related problems surfaced as a result of the library's status as a depository for government documents and patents. There was concern when it was learned that U.S. patents, trademarks, and their associated literature would not be accessible for six weeks. Librarians suggested several options for the callers. For example, depository libraries are available in Alabama and South Carolina. The Patent and Trademark Office's homepage provided some access, but was not fully operational during the Games. Fee-based options were available for trademark searching, and while many searches were performed, most callers opted to wait for the campus to reopen. Librarians noted, by the way, that a significant number of callers were seeking trademarks for "Atlanta 96," which was federally registered for exclusive use by ACOG.

Interlibrary loan and document delivery were also affected. Books were delivered via UPS rather than by U.S. mail at library rate, and photocopies were faxed. The library became a nonsupplier on OCLC from June 30 to August 15 and offered infrequent service to Georgia libraries only.

Workflow patterns in technical services were noticeably hampered by the Games, since all incoming U.S. mail was delivered to an offcampus location and $\mathrm{X}$-rayed. The mail was loaded on a shuttle, sealed, and allowed to enter campus only once a day at a designated time. Periodical issues were regularly received, but boxes of materials were usually delayed several days. After the Centennial Olympic Park bombing, no large boxes were received.

In anticipation of mail delays, library staff asked vendors to hold all approval and standing order shipments until the conclusion of the Games. These delays further affected workflows in acquisitions and cataloging. Flexible scheduling of Systems Department staff also had an impact on processing; since bibliographic records were not exported on a daily basis, record editing was difficult. Bindery operations were suspended during the secure period, because the bindery delivery truck could not access the campus. When the Games concluded and deliveries of books and serials resumed on a regular basis, technical services staff collaborated to catalog and process these backlogged materials promptly. 


\section{The realities of telecommuting}

Although librarians in technical services could not telecommute easily, telecommuting was a viable option for several librarians in other departments. The librarians in the Corporate Research Services Department, a feebased unit that conclucts online literature searches for clients, prepared a proposal for telecom-muting. Several reference librarians also expressed interest in this possibility. Since telecommuting had not been done on a formal basis and no policies existed for it, many is-

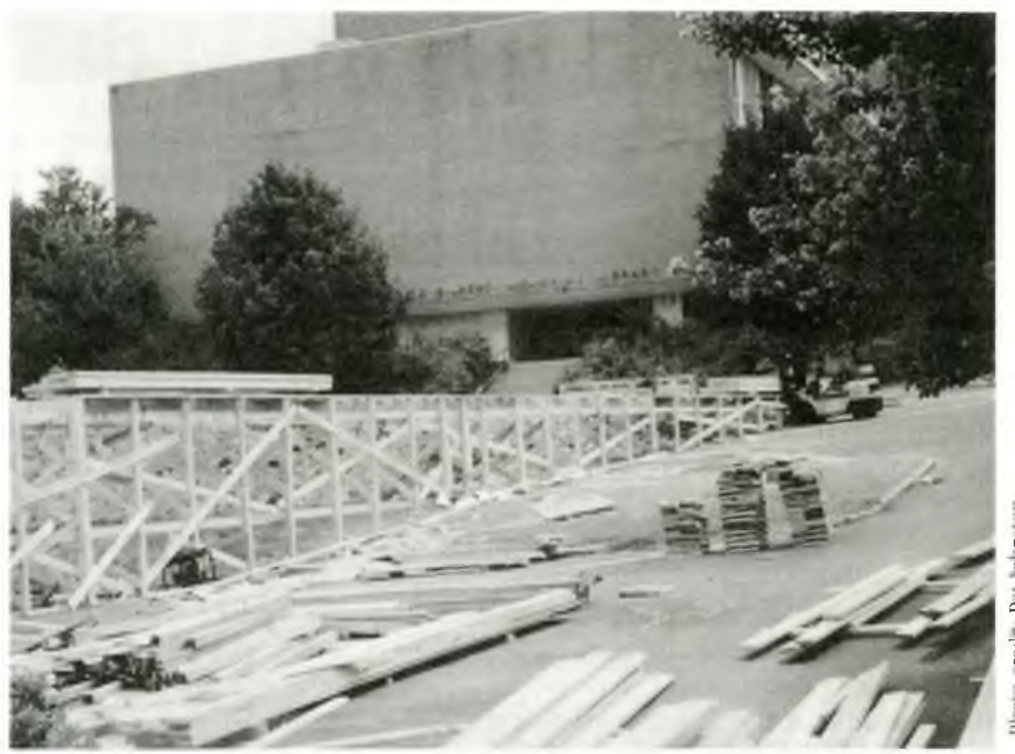

The Georgia Tech Library's parking lot in transition from a regular campus facility to one of the venues for hosting the 13,500 athletes who participated in the Olympic Games in Atlanta last summer.

sues surfaced for discussion.

For three days each week, librarians in the fee-based unit conducted database searches from their homes. Research requests remained at a near-normal level, and requests for trademark searches increased during the Games, since customers were unable to come to the library to use the Patent \& Trademark Office's CASSIS system. Reference librarians worked on collection development and on finding relevant Web sites for the library's homepage.

The telecommuting experiment was a success. Productivity and services were maintained. and the librarians appreciated the flexibility in their scheclules. However, the delineation between work life and home life became blurred at times. Occasionally, the librarians experienced feelings of isolation and even boredom in being away from their colleagues and remaining all day in the same environment. They wondered about the potential effects of longterm telecommuting on one's sense of identification with the organization. Overall, though, telecommuting was a positive experience, and the librarians recommencled that telecommuting options be explored for the future.

\section{The "Move"}

The library anticipated that the number of information requests from faculty and students would be considerably less than usual during the summer of 1996. This was viewed as an opportunity to implement a plan alleviating space problems by transferring all pre-1980 periodical volumes to a renovated area in the basement of the library, in which compact shelving had been installed. These activities were referred to as the "Move." In addition to numerous, newly hired student assistants, virtually all of the professional and classified staff of the library participated in the move

Before they were relocated, appropriate volumes were tagged for transport. These volumes were removed from the shelves, placed on an assembly line of book trucks, cleaned and vacuumed, and moved to the compact storage area. As the volumes were reshelved in compact storage, barcodes in the volumes were scanned to facilitate changes of location information in catalog records. Nearly 30,000 linear feet of pre 1980 volumes were transferred in this manner.

The move constituted an enormous librarywide effort, and success depended on effec tive teamwork. From mid-June through late August, four daily shifts of 15 individuals per shift worked on the move. People dressed casually and comfortably, and as a reward for staff efforts, three special lunches were catered by a restaurant on campus. Staff responded well to this dramatic change from routine activities. 


\section{Library staff discovered they were in the middle of the place everyone wanted to be but couldn't=the Olympic Village.}

Schwarzenegger and Vanessa Williams made guest appearances. President Clinton made a speech in the Village. Many staff used their breaks and lunch times to take photographs, mingle with the athletes, and participate in pin trading. Staff met and talked with people from all over the world. and found that

\section{Changing Olympic perspectives}

To say working in the Olympic Village was inconvenient would be an understatement. Staff frustration before the Olympic secure period was high. Dire predictions were being macle about traffic congestion, and procedural changes and new restrictions were publicized almost daily. As the athletes began arriving and the campus was transformed into the Olympic Village, the festive atmosphere helped to lift spirits. Library staff discovered they were in the middle of the place everyone wanted to be but couldn't-the Olympic Village.

Library staff had virtually unlimited access to the Olympic Village, which included the opportunity to participate in activities for the athletes. Free concerts and performances were ongoing in the center of campus, and the cafe offered free coffee and beverages for everyone in the Village, not just the athletes. The Village hosted the international premiere of the action film Eraser, and stars Arnold the Olympic spirit was infectious.

At the end of the Games, some library staff temporarily experienced a letdown, since many years of planning and effort had been devoted to several quick weeks of athletic competition. Looking back, it seems that the Games opened and closed simultaneously. Being in the middle of the Olympic Village was a wonderful and once-in-a-lifetime experience. The athletes and their competitions, the international visitors, and the star-filled ceremonies contributed to a unique ambiance. People with different languages, social customs, and political perspectives competed and shared as members of a global village. The Georgia Tech Library and Information Center staff were proud participants in this village's activities and events

\section{Note}

1. Anne Rochell, Kristin Fddy, and Lillian Lee Kim, "Spirit of Kinship Abounds in 'City'," Atlanta Constitution (July 11, 1996): \$16.

\section{C\&RL News 30th anniversary quiz}

Here is the next installment of the CERL News 30 th anniversary quiz. Test your recollection of events that have been reported in the News since 1966.

1. According to Hardy Franklin, 1994 ALA presiclent, what is at the heart of the library profession?

2. What was Zel)'s (a student) suggestion for improving his university's library in 1992?

3. When did the Board of Directors vote to establish a Bibliographic Instruction Section (now known as the Instruction Section) within ACRL?

4. What did participants think about the first ACRL National Conference held in Boston in 1978 ?

5. On May 5.1972, library history was made when a class action suit challenging the constitutionality of a state statute was filed in federal court on behalf of all librarians and library employees of that state. Name the state and the statute.

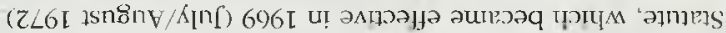

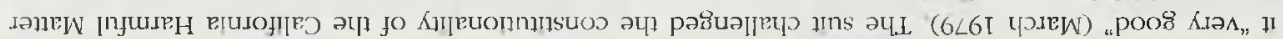

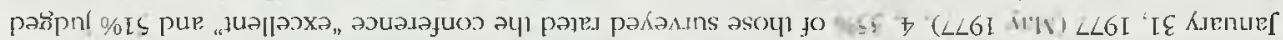

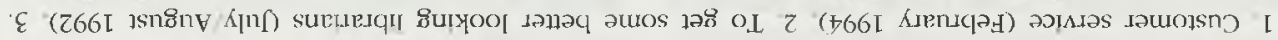




\section{ACRL's 8th National Conference was a resounding success!}

\section{ACRL thanks those who helped make it possible.}

National Conference

Executive Committee

ie Carla Stoffle, chair

¿ Joseph Boissé, colleagues

2. Margo Christ, commissioned papers

- Barbara MacAdam, contributed papers

Karen Downing, contributed papers

r. Jack Walsdorf, exhibitors advisory

s. Shirley Hallblade, local arrangements

s. Bill Robnett, local arrangements

z. Hannelore Rader, panel programs

danice Simmons-Welburn, poster sessions

re Chris Filstrup, preconferences

i. Marianne Gaunt, preconferences

re Joe Weed, publicity

ze Lizbeth Bishoff, scenarios

Sherrie Bergman, theme speakers

i. Betty Tsai, roundtables

- Claudette Hagle, roundtables

2. David McDonald, technology

re Robert Renaud, intern

re Jerilyn Veldof, intern

ce Catherine Larson, intern
ACRL National Conference Colleagues

Summa Cum Laude (over $\$ 5,000$ )

s. Blackwell North America

2. Chadwyck-Healey

EBSCO Subscription Services

re Innovative Interfaces

- Information-Access Company

2. Swets \& Zeitlinger

H. W. Wilson Foundation

Magna Cum Laude $(\$ 1,000-\$ 5,000)$

2. Academic Book Center

ie Faxon Company

s. SilverPlatter

2. UMI

ie Yankee Book Peddler

Cum Laude (\$500-\$999)

te Baker \& Taylor

re Institute for Scientific Info.

s. Midwest Library Service

2. SOLINET

spacesaver Corporation

And all of the speakers, moderators, roundtable facilitators, poster session presenters, volunteers, exhibitors, and attendees.

P.S. Save April 9-12, 1999, for ACRL's 9th National Conference in Detroit. 